\title{
ニューラルネットワークを用いた石油製品性状推定の検討 ${ }^{\dagger}$
}

\author{
山本順三 ${ }^{1 \dagger+}$ ・佐々木隆志 ${ }^{1} \cdot$ 花熊克友 $^{1}$ ・中西英二 ${ }^{2}$
}

1出光エンジニアリング(株)，260-0027 千葉市中央区新田町 37-24

2関西大学工学部 化学工学科, 564-8680 吹田市山手町 3-3-35

\begin{abstract}
ニューラルネットワークの実用性を検討するために, 常圧蒸留装置の軽油 $90 \%$ 蒸留点, 燃料油のリサー チオクタン価, 及びナフサスプリッターの引火点を対象としたニューラルネットによるモデル化の検討を 行った. 使用したニューラルネットワークの種類は, Back Propagation ニューラルネットワーク, Radial Basis Function ニューラルネットワーク, および Wave-net である. 光の結果, 定常状態のデータを用い た静的モデルの作成においては, Radial Basis Functionニューラルネットワークと Back Propagation ニューラルネットワークが優れていることがわかった。.また，時系列データを用いた動的モデルの作成に おいては, Wave-netが優れていることがわかった.
\end{abstract}

\section{緒言}

化学プラントの運転に際しては, 製品品質などのオンライン測 定が困難な状態量を推定することが重要な課題である。そのため には, プラントの温度, 圧力, 流量など直接測定可能な運転変数 から製品品質を推定することが必要となる。しかし，厳密なプロ セスモデルを作成することは実際には困難が多く，作成する場合 には多大な労力を要する，また，統計解析的な線形モデルで近似 することは, 対象プロセスが非線形で複雑になることが多いため, 精度の面で問題があった。

対象の非線形性を表現するために，ニューラルネットワークが 使用されている (McAvoy，1993）。これまで，基底関数（basis function)の種類, ネットワークの構造, 学習のアルゴリズムの違 いによって, 様々なニューラルネットワークが提唱されている. 本研究では, 常圧蒸留装置の軽油 $90 \%$ 蒸留点, 燃料油のリサーチ オクタン価, ナフサスプリッターの引火点を対象に, Back Propagation ニューラルネットワーク (Rumelhart et al., 1986), Radial Basis Function ニューラルネットワーク (Poggio and Girosi, 1990)，およびWave-net (Bakshi and Stephanopoulos, 1993) を用いてプロセスモデルを構築し, 各々の実用性能を比較検討し た.

\section{1. ニューラルネットワークモデル}

(1) Back Propagationニューラルネットワーク Back Propagation ニューラルネットワークは入力および出力に対応す るニューロンを与え，入力と出力の間に何層かの中間層を持った 階層構造になっている. 本研究で用いた Back Propagation二ュ ーラルネットワークの構造を Fig. 1 に示す. 各ニューロンの入力 に対する重みと閾値を入出力デー夕を用いた学習によって調節す ることにより，入出力関係を見出すものである，基底関数には次 式で示すシグモイド関数を用いる.

$\dagger 1998$ 年 4 月 2 日

計測自動制御学会第 6 回制御技術シンポジウム（東京，1998 年 4 月）に て発表

†† QWF $03420 @$ niftyserve. or. jp

$$
f(x)=\frac{1}{1+\exp (-x)}
$$

ここで, $x$ はシグモイド関数への入力である.パラメータである 重みと閾值は, 教師信号と出力との誤差の自乗和を最小にするよ うに，最急降下法によって求められる.

(2) Radial Basis Function ニューラルネットワーク 本研 究で使用した Radial Basis Functionニューラルネットワークの 構造を Fig. 2 に示す. 入力層のニューロンは, Back Propagation ニューラルネットワークと同様に入力を格納するだけのものであ り，入力層から中間層のニューロンへの重みは全て 1 である. 中間層の二ューロンの数を $\mathrm{m}$ とすると, 中間層の $\mathrm{k}$ 番目の二ュ 一ロンからの出力 $\phi_{\mathrm{k}}(\boldsymbol{x})$ は, 一般に, 次式のガウシアン関数によ って与えられる。

$$
\phi_{\mathrm{k}}(\boldsymbol{x})=\exp \left(-\frac{\left\|\boldsymbol{x}-\boldsymbol{c}_{\mathrm{k}}\right\|^{2}}{\beta^{2}}\right)
$$

ここで, $x$ は入力ベクトル， $\boldsymbol{c}_{\mathrm{k}}$ は $\mathrm{k}$ 番目のニューロンの中心, $\beta$ は関数の形状を決める感度パラメータである.また, \|\|$\|$ はユー クリッドノルムである. 出力層からの出力 $\hat{y}_{R B F}$ は, 中間層の出力 の線形結合と閥值 $\theta$ の和で表される.

$$
\hat{y}_{\mathrm{RBF}}=\sum_{\mathrm{k}=1}^{\mathrm{m}} w_{\mathrm{k}} \phi_{\mathrm{k}}(\boldsymbol{x})+\theta
$$

ここで, $w_{\mathrm{k}}$ は重みパラメータである. $\beta$ は試行錯䛊的に決める 必要があるが, $\boldsymbol{c}_{\mathrm{k}}, w_{\mathrm{k}}, \theta$ は最小自乗法的に求まる。実際の学習 では, まず中間層のニューロンの数を 1 つから始め, 入力デー夕に 対して $\boldsymbol{c}_{\mathrm{k}}, w_{\mathrm{k}}, \theta$ を求め, 許容誤差と比較する. 許容誤差を満た せば終了し, 許容誤差を満たさなければ, 中間層のニューロンの 数を 1 つ増やし再度計算する. 以降, 同様の処理を順次実施しモデ ルを作成することになる，入力デー夕の数だけ，ニューロンを用 意することにより許容䛊差を満足することが可能となるため, 通 常, 最大許容ニューロン数を決めておき, 許容誤差を満足するか, または最大許容ニューロン数に達したときに学習は終了するよう にする。

Radial Basis Functionニューラルネットワークの特長として は, 基底関数に使用しているガウシアン関数の局所的な性質, つ まり入力ベクトル $x$ がニューロンの中心 $c_{\mathrm{k}}$ に近くないと十分な 值として出力しないことが挙げられる.このことが, Back Propagation ニューラルネットワークのようなグローバルな基底関数 


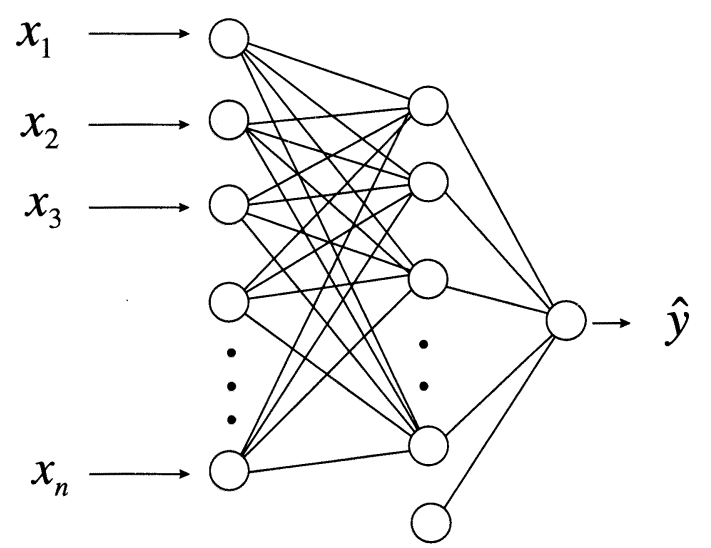

Input layer Hidden layer Output layer

Fig. 1 The structure of Back Propagation neural network

を用いるネットワークに比較して有利な点となる.

(3) Wave-net Wave-netは, Wavelet 関数を基底関数に 用いたネットワークであり, Radial Basis Function ニューラルネ ットワークと同様の構造を持つ. 入力 $\boldsymbol{x}$ に対する出力層からの出 力 $\hat{y} \mathrm{w} \_\mathrm{N}$ は, Wavelet 関数と重みパラメータの積和で表される.

$$
\hat{y}{ }_{\mathrm{W}}{ }_{-\mathrm{N}}=\sum_{\mathrm{m}=1}^{L} \sum_{\mathrm{k}} c_{\mathrm{mk}} \psi_{\mathrm{mk}}(\boldsymbol{x})+\sum_{\mathrm{k}} d_{\mathrm{LK}} \phi_{\mathrm{LK}}(\boldsymbol{x})
$$

ここで, $\phi_{\mathrm{mk}}(\cdot)$ は, スケール $\mathrm{m}$, 置換 (translation) $\mathrm{k}$ である Wavelet 関数, L は最も粗いスケール， $\phi_{\mathrm{LK}}(\cdot)$ はスケーリング関 数, $c_{\mathrm{mk}}, d_{\mathrm{LK}}$ は各々の重みパラメータである. そしてモデル出力 と教師データの詰差 ( $\mathrm{L}^{\infty}$ ノルム) を最小にするように各々のパラ メー夕を求める.

$$
\min _{\mathrm{c}} \max _{\mathrm{k}}\left|\hat{y}_{\mathrm{kW}}{ }_{-}-y_{\mathrm{k}}\right|
$$

ここで， $\bar{y}_{\mathrm{kW} \_N}$ は Wave-net の出力， $y_{\mathrm{k}}$ は教師信号である.ま た, Eq. (5)の最大最小問題は線形計画法 (Linear Programming) を用いて解くことになる. 実際の学習では, 予め基底関数に用い るスケーリング関数と Wavelet 関数の組, 最も粗いスケール, 許 容誤差を決めておく，入力デー夕に対して最も粗いスケーリング 関数から始め, 重みパラメー夕を求め出力を計算し, 許容誤差と 比較する．許容誤差を満たせば，次のデー夕に対して同様の処理 を行う．許容誤差を満たさなければ，より精密なスケールの Wavelet 関数を導入し, 再度デー夕に対して, 重みパラメー夕を 求め, 許容䛊差と比較する. 以降, 同様の処理を順次実施し, モ デルを作成することになる.

Wave-net の特長としては, 基底関数に使用している Wavelet 関数の局所的な性質と共に, 多様なスケールを対象に応じて適用 することができる多解像 (Multiple Resolution) な性質がある. このため, モデルの評価に，推定誤差である精度だけでなく，モ デルの滑らかさが導入可能となる.

また, Radial Basis Functionニューラルネットワークと Wave -netの共通の特長として, 事前に中間層の層数を決める必要がな いため, モデル作成のための設計パラメータが少ないことが挙げ られる.つまり, Back Propagationニューラルネットワークは, 中間層の層数, 中間層の二ューロン数, 許容誤差（または, 最大 許容学習回数) を予め決めてから学習をする必要があるのに対し, Radial Basis Function ニューラルネットワークは, 感度パラメー 夕の值, 許容誤差（または, 最大許容ニューロン数）を予め決め てから学習をする，同様にWave-netは，最も粗いスケール，許 容誤差 (または, 最大許容 Wave-let 関数の数)を子予決めてから

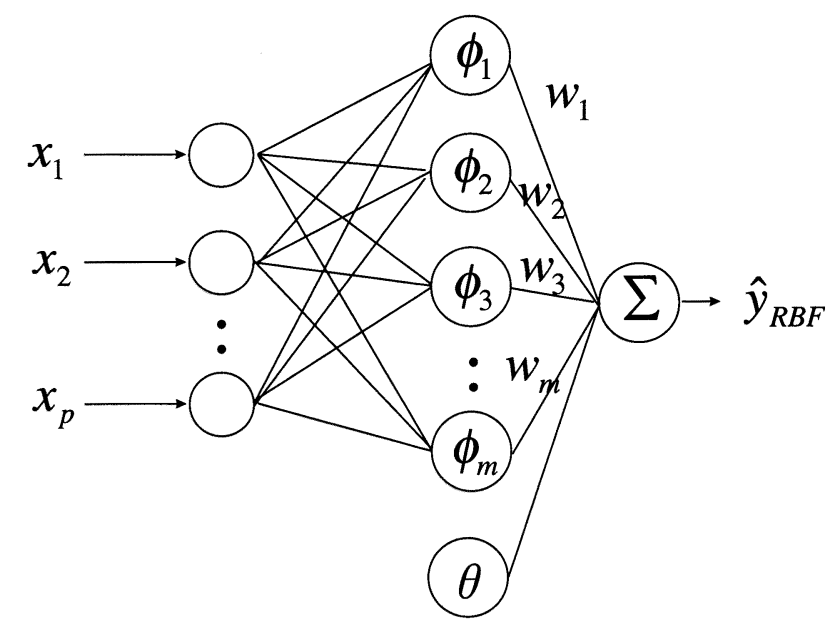

Fig. 2 The structure of Radial Basis Function neural network 学習をする.

\section{2. 燃料油品質推定における適用結果}

燃料油の品質の一つであるリサーチオクタン価を推定すること を検討した。リサーチオクタン価は，燃料油のアンチノック性を 示す尺度であり, 火花点火式エンジンを使用して測定される。 こ れまで，実際の製造工程においては，製品のラボ試験を実施する か, または, 測定原理が同じであるエンジン式の分析計が用いら れていた. しかし，ラボ試験では連続的に測定できないこと，工 ンジン式の分析計は設置に大きなスペースを要し, 信頼性が低く メンテナンスの負荷が高いなどの理由から, 容易に, かつ精度良 く測定する方法が望まれていた。

筆者らは，燃料油のリサーチオクタン価を推定する方法として， 燃料油の組成分析デー夕を入力とし, Back Propagationニュー ラルネットワークを用いたニューラルネットワークモデルを構築 し，その実用性を示した (Yamamoto et al., 1998). 通常, 燃料 油の全組成ガスクロマトグラフ分析では, 約 180 成分に分離され るが, ガスクロマトグラフ分析自体に時間を要するため, 測定時 間短縮のために代表的な 19 のピークにまとめられる（Ishikawa， 1991). 本論文では，この燃料油の代表的な 19 の組成分析デー夕 (各組成重量分率)をモデルの入力変数とし, モデル作成用データ セット 33 件を用いて Back Propagationニューラルネットワー クモデル, Radial Basis Functionニューラルネットワークモデ ル, Wave-net モデルを作成し, 検証用データセット 9 件にて検証 を行った。 なお, ニューラルネットワークを用いる際は, オーバ ーフィッティングの可能性があるため, モデル作成用デー夕にお ける推定結果だけでは妥当な推定モデルかどうかの判断が難しい. Fig. 3(a) オーバーフィッテングのイメージ図を示す。モデル作 成用デー夕に対して, オーバーフィッティングしたモデルは, 逆 に検証用データに対して誤差が大きくなる可能性がある. Fig. 3(b) に, モデル作成用デー夕に対する推定結果, 検証用デー夕に 对する推定結果, およびニューロン数などの設計パラメータの関 連を表現した概念図を示す。ニューロンの数を増やすことにより， モデル作成用のデー夕に対しては，よりフィッティングするが, 逆に増やし過ぎるとオーバーフィッティングになり, 検証デー夕 に対する精度が悪化する．このことから，各々のニューラルネッ トワークにおける最適なモデルの構造は, 検証用デー夕に適用し た際の推定精度を参考に決定し, 検討を行った。

ニューラルネットワークモデルとの比較のため, 最小 2 乗法を 
Table 1 Result of standard deviation of estimation error for Research Octane Numbery by statistical model and three neural networks models

\begin{tabular}{|c|c|c|}
\hline & result for learning data & result for test data \\
$\begin{array}{c}\text { standard deviation of estimation } \\
\text { error by statistical model }\end{array}$ & 0.11 \\
\hline $\begin{array}{c}\text { standard deviation of estimation } \\
\text { error by Back Propagation Neural } \\
\quad \text { Networks model }\end{array}$ & 0.10 \\
\hline $\begin{array}{c}\text { standard deviation of estimation } \\
\text { error by Radial Basis Function } \\
\text { Neural Networks model }\end{array}$ & 0.13 \\
\hline $\begin{array}{c}\text { standard deviation of estimation } \\
\text { error by Wave-net model }\end{array}$ & 0.14 & 0.25 \\
\hline
\end{tabular}
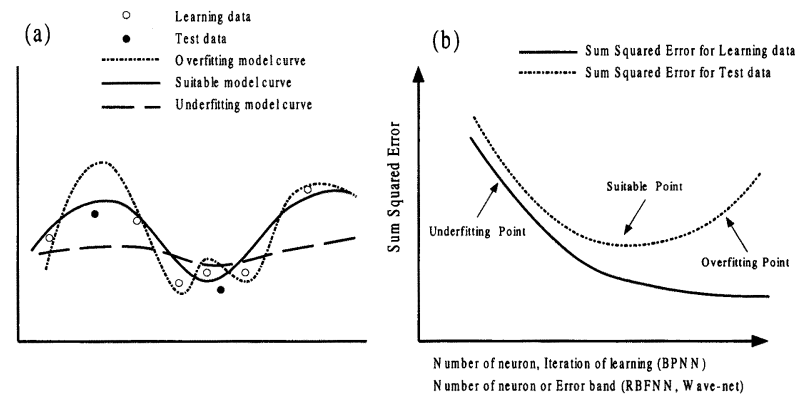

Fig. 3 The concept of overfitting and the relation between Sum-squared error and design parameter

用いて統計モデルを作成した. Fig. 4(a) に統計モデルの検証結 果を示す，検討においてはデー夕の最大值，最小值に適度な余裕 を考慮した值によって0〜1に正規化したデー夕を用いて実施し ている.

(1) Back Propagationニューラルネットワークモデル ネットワークの構造は, 入力 19 , 中間層 8, 出力 1 とした. 中間層 のニューロン数は, 各々 $5 \sim 20$ にした 16 通りのニューラルネット ワークを試行し, 学習データとテストデータの精度（推定誤差の 標準偏差）の差が近く，またテストデータにおいて最も精度の良 かった中間層のニューロン数 8 を最適な構造と判断し採用した. 学習回数は 1,000 回である. Fig. 4(b) にモデル作成に用いてい ないデータセット 9 組での検証結果を示す.

(2) Radial Basis Functionニューラルネットワークモデル 許容誤差を 0.03 , 感度パラメータ $\beta$ を 1 とし，モデルを作成し た. 最終的なニューロンの数は 16 であった. 許容誤差は実用上要 求される推定精度から妥当と考えられる值を初期值として与え, より良いモデルを作成するために, 0.01 0.1の間で, 感度パラメ 一夕は 0.01 0.1の間で各々試行し, テストデー夕において最も 精度（推定誤差の標準偏差）が良かった值を採用した. Fig. 4 (c) に検証結果を示す。

(3) Wave-net モデル ウェーブレット関数とスケーリン グ関数は,「Mexican-Hat」関数を使用している（Bakshi and Stephanopoulos, 1993). 許容䛊差は実用上要求される推定精度か ら妥当と考えられる值を初期值として与え，より良いモデルを作 成するために, 0.01〜0.1の間で試行し, テストデータにおいて最 も精度の良かった 0.04 を採用した.フィッティングに要した Wave-let 関数の数は 19 である. Fig. 4 (d) に検証結果を示す.

Table 1 に各々モデルの学習, および検証用データセットでの 推定誤差の標準偏差を示す. 統計モデルにおいては，モデル作成 に用いた 33 組の学習用データセットでは良い精度で推定されて
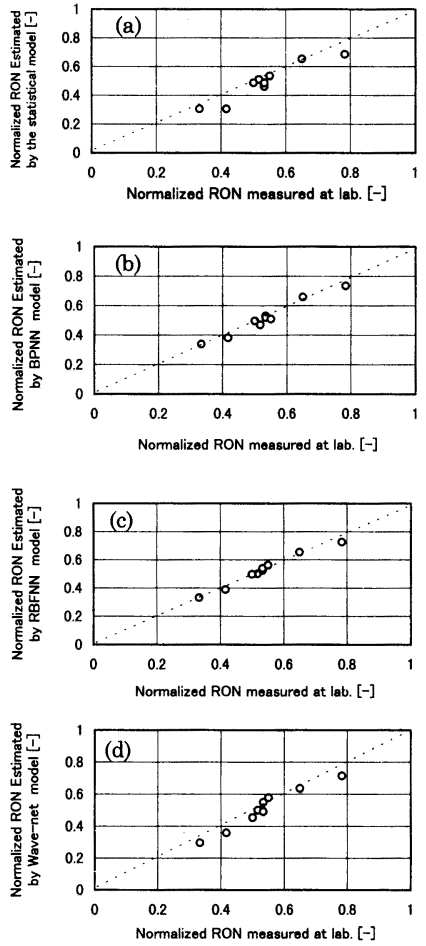

Fig. 4 The relationship between real Research Octane Number measured at laboratory and estimation results on test data by (a) the statistical model, (b) the Back Propagation neural networks model (c), the Radial Basis Function neural networks model, and (d) the Wave-net model

いるが，作成に用いていない 9 組のデータセットによる検証結果 での精度は低下している。一方，ニューラルネットワークモデル の検証結果における推定精度は, 統計モデルに比較して, 精度良 く推定していることがわかる. また，ニューラルネットワークモ デルの中では, Radial Basis Function ニューラルネットワークモ デルが他のニューラルネットワークモデルに比較して, 精度良く 推定していることがわかる.

各々の検証結果において, 推定結果がラボ試験值に対して低く 推定されている傾向にある. 今回検討に用いたデー夕は, すべて 通常運転範囲中のデータである，モデル作成用データと検証用デ 一タはランダムに振り分けたが, ラボ試験の頻度が約 1 回/週程度 であるため, データセットの総数が少なく, 結果として, データ のランダム性が少し損なわれた可能性がある.このため, 推定結 果がラボ試験值に対して低く推定される傾向にあると考えられる. 
Table 2 Result of standard deviation of estimation error for LGO 90\% Boiling Point by statistical model and three neural networks models

\begin{tabular}{|c|c|c|}
\hline & result for learning data & result for test data \\
$\begin{array}{c}\text { standard deviation of estimation } \\
\text { error by statistical model }\end{array}$ & 2.71 \\
\hline $\begin{array}{c}\text { standard deviation of estimation } \\
\text { error by Back Propagation Neural } \\
\quad \text { Networks model }\end{array}$ & 1.96 \\
$\begin{array}{c}\text { standard deviation of estimation } \\
\text { error by Radial Basis Function } \\
\quad \text { Neural Networks model }\end{array}$ & 1.81 \\
\hline $\begin{array}{c}\text { standard deviation of estimation } \\
\text { error by Wave-net model }\end{array}$ & 2.19 \\
\hline
\end{tabular}
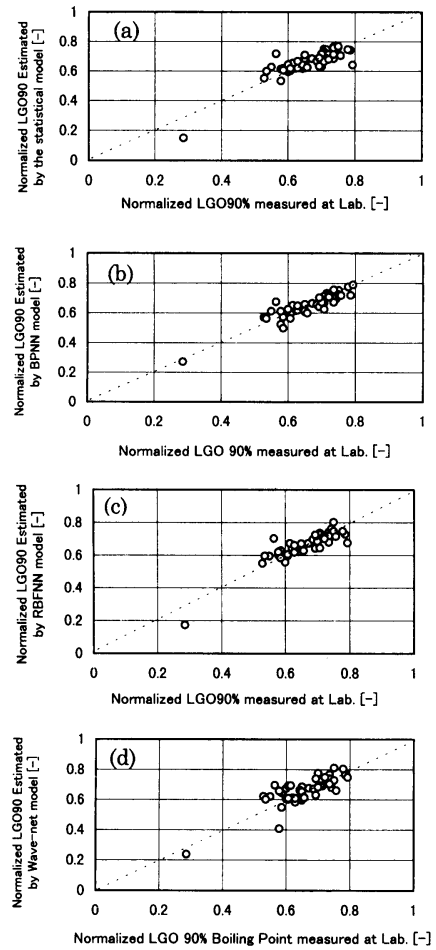

Fig. 5 The relationship between real LGO 90\% Boiling Point measured at laboratory and estimation results on test data by (a) the statistical model, (b) the Back Propagation neural networks model (c), the Radial Basis Function neural networks model, and (d) the Wave-net model

\section{3. 常圧蒸留藚における適用結果}

常圧蒸留装置は原油を加熱し，ガス留分，ナフサ，灯油，軽油， 重質軽油，重油に分留する装置である，装置の温度，圧力などの 運転変数から軽油（Light Gas Oil）の品質である $90 \%$ 蒸留点を 推定するモデルを作成した，モデルの入力変数は，これまで構築 した経験式の中で使用した運転変数を参考に, チャージ流量, 千 ヤージ温度, 塔頂温度, 塔頂圧力, 軽油抜出温度, 軽油抜出流量 などの品質と相関があると考えた 17 運転変数を選択した. 定常状 態での運転デー夕を用いているため, 入力変数と出力変数間の時 間遅れは考慮しない静的モデルを構築した。モデル作成用データ セット 108 組を用いてモデルを作成し, 検証用データセット 54 組 にて検証を行った。

ニューラルネットワークモデルとの比較のため, 最小 2 乗法を 用いて統計モデルを作成した．Fig.5(a) に統計モデルの検証結
果を示す.

(1) Back Propagationニューラルネットワークモデル ネットワークの構造は, 入力 17 , 中間層 10 , 出力 1 とした。間 層のニューロン数を各々 5 19にした 15 通りのニューラルネッ トワークを試行し，学習データとテストデータの精度（推定誤差 の標準偏差）の差が近く，またテストデー夕において最も精度の 良かった中間層のニューロン数 10 を最適な構造と判断し採用し た. 学習回数は 5,000 回である. Fig. 5(b) にモデル作成に用いて いないデータセット 54 組での検証結果を示す.

(2) Radial Basis Functionニューラルネットワークモデル 許容誤差を $0.08, \beta$ を 1.95 とし，モデルを作成した。最終的な二 ユーロンの数は 29 であった. 許容誤差は実用上要求される推定精 度から妥当と考えられる值を初期值として与え, より良いモデル を作成するために, 0.05〜0.15の間で, 感度パラメータは 0.1〜 10 の間で試行し，テストデータにおいて最精度（推定誤差の標準 偏差）が良かった値を採用した。 Fig. 5(c) に検証結果を示す.

(3) Wave-net モデル ウェーブレット関数とスケーリン グ関数は,「Mexican-Hat」関数を使用している. 許容誤差は実用 上要求される推定精度から妥当と考えられる值を初期值として与 え，より良いモデルを作成するために，0.03〜0.1の間で試行し， テストデータにおいて最も精度（推定誤差の標準偏差）の良かっ た 0.055 を採用した. フィッティングに要した Wave-let 関数の 数は 59 である. Fig. 5 (d) に検証結果を示す.

Table 2 に各々モデルの学習, および検証用データセットでの 推定誤差の標準偏差を示す.ニューラルネットワークモデルの検 証結果における推定精度は, 統計モデルに比較して, 精度良く推 定していることがわかる。また，ニューラルネットワークモデル の中では, Back Propagationニューラルネットワークモデルと Radial Basis Functionニューラルネットワークモデルが Wavenetに比較して，精度良く推定していることがわかる.

\section{4. ナフサスプリッターにおける適用結果}

ナフサスプリッターの塔底製品である重質ナフサの引火点を推 定するモデルを作成した. この重質ナフサは，下流の装置へフィ 一ドされるため，ここでの品質はオンライン分析計にて 5 分周期 で測定され，常時モニタリングされている。しかし，サンプルラ インの遅れなどがあること，および分析計稼動状況のチェックを する必要があることから引火点を推定するモデルを検討した．約 2 日分の時系列デー夕 (5 分周期) を用いてモデルを作成し, 残り の約 2 日分のデータにて検証を行った.

なお, 重質ナフサの引火点は, これまでの経験から塔底温度と 
Table 3 Result of Integral of absolute error for Flash point by statistical model and three neural networks models

\begin{tabular}{|c|c|c|}
\hline $\begin{array}{c}\text { IAE of estimation error } \\
\text { by statistical model }\end{array}$ & result for learning data & result for test data \\
\hline $\begin{array}{c}\text { IAE of estimation error by Back } \\
\text { Propagation Neural Networks model }\end{array}$ & 53.2 \\
\hline $\begin{array}{c}\text { IAE of estimation error by Radial Basis } \\
\text { Function Neural Networks model }\end{array}$ & 55.3 \\
\hline IAE of estimation error by Wave-net \\
nodel
\end{tabular}
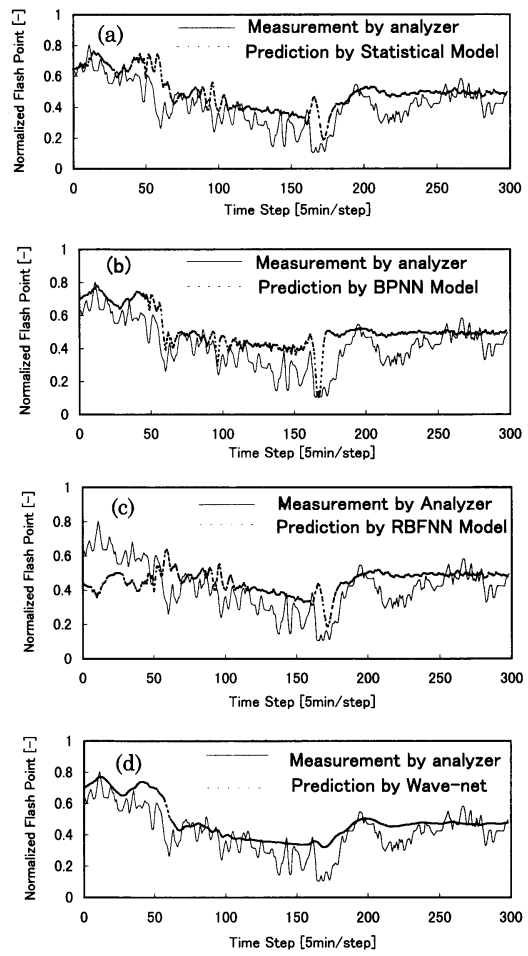

Fig. 6 The Flash point prediction on test data by (a) the statistical model, (b) the Back Propagation neural networks model, (c) the Radial Basis Function neural networks model, and (d) the Wave-net model

強い相関があることがわかっているため, モデルの入力変数は塔 底温度とした。また，時間遅れとモデル次数の選択は，これまで の経験と相関係数が最大となる組合せにて決定した。

$$
\boldsymbol{x}(t)=[u(t-\delta-1), \cdots, u(t-\delta-\xi)]^{T}
$$

$\hat{y}_{\mathrm{NN}}(t)=F_{\mathrm{NN}}[x(t)]$

ここで $\boldsymbol{x}$ は入力べクトル， $u$ は入力変数である塔底温度, $\delta$ は むだ時間 $(\delta=4), \xi$ はモデル次数 $(\xi=5), \hat{y}_{\mathrm{NN}}$ は引火点推定值, $F_{\mathrm{NN}}$ はモデリングに用いたニューラルネットワークモデルを示す。 ニューラルネットワークモデルとの比較のため, 最小 2 乗法を 用いて統計モデルを作成した．Fig. 6(a) に統計モデルの検証結 果を示すままた，検討に用いた時系列デー夕は，平滑化をしてい ない生データを用いている。これは，ノイ・ズの意味を判断するこ とができないケースがあること，およびニューラルネットワーク のような非線形のモデリング手法において，ノイズに対する過剩 なフィティングの有無を確認するためである.

(1) Back Propagationニューラルネットワークモデル ネットワークの構造は, 入力 5 , 中間層 4 , 出力 1 とした. 中間層 のニューロン数を各々 $2 \sim 8$ にした 7 通りのニューラルネットワ
ークを試行し, 学習データとテストデータのIAE (Integral of Absolute Error）の差が近く，またテストデー夕において最も精 度の良かった中間層のニューロン数 4 を最適な構造と判断し採用 した. 学習回数は 1,000 回である. Fig. 6(b) にモデル作成に用い ていない 2 日分のデータセットでの検証結果を示す.

(2) Radial Basis Functionニューラルネットワークモデル 許容誤差を $0.14, \beta$ を 0.9 とし，モデルを作成した，最終的な二 ユーロンの数は 5 であった。許容誤差は実用上要求される推定精 度から妥当と考えられる值を初期值として与え，より良いモデル を作成するために, 0.1 0.2の間で, 感度パラメー夕は $0.1 \sim 5$ の 間で検討し, IAEが最も良かった值を採用した. Fig. 6(c) に検証 結果を示す。

(3) Wave-net モデル ウェーブレット関数とスケーリン グ関数は,「Mexican-Hat」関数を使用している. 許容誤差は実用 上要求される推定精度から妥当と考えられる值を初期值として与 え, より良いモデルを作成するために，0.1０.2の間で試行し， IAEが最も良かった 0.15 を採用した.フィッティングに要した Wave-let 関数の数は 2 である. Fig. 6(d) に検証結果を示す.

Table 3 に学習, および検証用データセットでのIAEを示す. 静的モデルでは，標準偏差を計算しラボ試験值と推定值のバラツ キを評価したが，動的モデルでは，標準偏差を用いるとモデルの 位相遅れを評価できない場合があるため，オンライン分析計の出 力值との誤差の大きさである IAE を計算しモデル精度を評価し た. IAE は次式を用いている.

$$
\mathrm{IAE}=\sum_{\mathrm{i}=1}^{\mathrm{n}}\left|\hat{y}_{\mathrm{NN}}(t-\mathrm{i})-y(t-\mathrm{i})\right|
$$

ここで, $\hat{y}_{\mathrm{NN}}$ はニューラルネットワークモデルの推定值, $y$ はオ ンライン分析計出力値, $\mathrm{n}$ はデータセット数である. IAEによる検 証結果から Wave-net が他のモデルに比較して, 精度良く推定し ていることがわかる.また, Back Propagationニューラルネット ワークモデルや Radial Basis Functionニューラルネットワーク モデルでは，ノイズと思われる信号に対して過度にフィティング しているが, Wave-netではノイズを除いたような曲線にフィテ イングしており，非常に滑らかな推定結果になることがわかった.

\section{結}

本論文で示した検討範囲において，ニューラルネットワークモ デルは, 統計モデル（線形モデル）より，優れていることがわか る. この事実は, ニューラルネットワークが非線形対象の近似に 適していることを示している. 今回検討した三種類のニューラル ネットワークにおいては, 全体としてその実用性能に明らかな差 異は見られなかった．検討対象のデータや信号の性質によって優 劣がでてくると考えられる。しかし，どのような対象デー夕には， 
どのニューラルネットワークが適しているかといった確固たる知

見はない.

常圧蒸留装置, 燃料油の性状推定においては, Radial Basis FunctionニューラルネットワークとBack Propagationニュー ラルネットワークによる推定精度が Wave-netに比較して優れ ていた。しかし, ナフサスプリッターの引火点のように, 時系列 データを対象とした動的モデルを構築する場合には, 推定精度だ けでなく，推定結果のスムーズさについても考慮する必要がある. その点から, 時系列データに対するモデリング（動的モデル）に

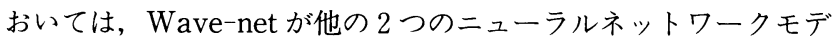
ルや線形モデルより優れていた.これは, Wave-netの目的関数に 推定結果のスムーズさと精度の両方を目的として取り込むことが できることに起因していると考えられる.

モデル構築の容易さという点では，1節で説明したように Radial Basis Functionニューラルネットワークと Wave-net は, 中間層の層数などモデル作成に必要な設計パラメータが少ないた め, Back Propagationニューラルネットワークより優れている. しかし, 感度パラメータや許容誤差などのパラメータは, 試行錯 誤的に決定しており, 今後これらのパラメータの有効な決定方法 を明らかにすることが課題である.今回の検討範囲においては, 上述のような検討結果になったが, 対象としたデータの性質に依 存する点も大きいため, 今後は他装置への適用を行い, これらの 知見を深めていきたい.

\section{Nomenclature}

$\begin{array}{ll}\boldsymbol{c}_{\mathrm{k}} & =\text { center vector of } \mathrm{k} \text {-th neuron } \\ \boldsymbol{c}_{\mathrm{mk}} & =\text { weight parameter of wave-let function } \\ d_{\mathrm{Lk}} & =\text { weight parameter of scaling function } \\ F_{\mathrm{NN}} & =\text { function of neural network model } \\ L & =\text { coarsest scale } \\ n & =\text { sample order }\end{array}$

$u=$ bottom temperature $\quad\left[{ }^{\circ} \mathrm{C}\right]$

$w_{\mathrm{k}} \quad=$ weight parameter of $\mathrm{k}$-th neuron $\quad[-]$

$x \quad=$ input variable $\quad[-]$

$\boldsymbol{x} \quad=$ input vector $\quad[-]$

$y_{\mathrm{k}} \quad=$ real value $\quad[-]$

$\hat{y}_{\mathrm{NN}}=$ the value estimated by Neural Networks models $[-]$

$\hat{y}_{\mathrm{RBF}}=$ the value estimated by Radial Basis Function Neural Networks models [-]

$\bar{y}_{\mathrm{w}}{ }_{-} \mathrm{N}=$ the value estimated by Wave-net models $\quad[-]$

$\beta \quad=$ sensitive parameter $\quad[-]$

$\delta \quad=$ dead time $\quad[\mathrm{min}]$

$\theta \quad=$ threshold value $[-]$

$\xi \quad=$ the order of dynamic model $\quad[-]$

$\phi_{\mathrm{k}}(\cdot)=$ Gaussian function $\quad[-]$

$\phi_{\mathrm{Lk}}(\cdot)=$ scaling function $\quad[-]$

$\psi_{\mathrm{mk}}(\cdot)=$ Wavelet function at scale $\mathrm{m}$ and translation $\mathrm{k} \quad[-]$

\section{Literature cited}

Bakshi, B. and G. Stephanopoulos, : Wave-net: A Multiresolution, Hierarchical Neural Network with Localized Learning," AIChE J., 39, 57 (1993)

Chen, S., C. F. N. Cowan, and P. M. Grant, : "Orthogonal Least Squares Learning Algorithm for Radial Basis Functions Networks," IEEE Transactions on Neural Network, 2, 302-309 (1991)

Ishikawa, Y.: Japan Patent 5-163493 (1993)

McAvoy, T., : "Application of Neural Network in the Chemical Process Industries," Proc. IEEE workshop, p. 2-9, Muroran, Japan (1993)

Poggio, T. and F., Girosi, : "Networks for Approximation and Learning," Proc. IEEE, 78, 1481-1497 (1990)

Rumelhart, D. E., G. E. Hinton and R. J. Williams : "Learning internal representations by error propagation," Parallel Distributed Process. ing, 1, 318-362 (1986)

Yamamoto, J., S. Sasaki, Y. Hanakuma, E. Nakanishi : "A Method of Estimating Research Octane Number of Gasoline by Neural Networks Model," Kagaku Kongaku Ronbunshu (to be published)

\title{
Estimation of Quality of Petroleum Products by Neural Networks Models
}

\section{JUNZO YAMAMOTO ${ }^{1}$, TAKASHI SASAKI ${ }^{1}$, YOSHITOMO HANAKUMA ${ }^{1}$ and EIJI NAKANISHI ${ }^{2}$}

\author{
${ }^{1}$ Engineering and Technical Service Center, Idemitsu Engineering Co., Ltd., Chiba 260-0027 \\ ${ }^{2}$ Department of Chemical Engineering, Kansai University, Suita 564-0073
}

\begin{abstract}
Key words: application, back propagation neural networks, quality estimation, radial basis function neural networks, Wave-net, petroleum products.

The performance of artificial neural networks on building process models for estimating the quality of petroleum products, research octane number of gasoline, boiling point of gas oil of a topping unit, and flash point of bottom product of a naphtha splitter, are examined in this study. Three types of artificial neural networks models are developed in this study; back propagation neural network, radial basis function neural network and Wave-net. It is shown that radial basis function neural network model and back propagation neural network model are superior to the other neural networks models on building a steady state model. Wave-net is useful in building a dynamic model for time series data.
\end{abstract}

